\title{
Death of Mr. V. H. Umbricht, honorary member of the ICRC
}

The ICRC was profoundly saddened by the death, on 14 July 1988 , after a very long illness, of Mr. Victor $\mathrm{H}$. Umbricht, honorary member of the ICRC and former Vice-President of the institution.

Mr. Umbricht served the ICRC for almost 20 years, a period of profound change for the institution during which his personality and achievements played an important role. He became a member of the International Committee in 1970 and three years later a member and Vice-President of the ICRC's Executive Board before being appointed Vice-President of the ICRC, a post he held until 1985. He was made an honorary member of the International Committee in 1986.

Mr. Umbricht was born in Endingen, Switzerland, in 1915. After obtaining a doctorate in international law from the University of Bern, he entered the Swiss Diplomatic Service where he served from 1941 to 1953. In that year he was appointed Deputy Director of Operations for Europe, Africa, Asia and Australasia at the World Bank in Washington, and in 1957 became Director General of the Federal Finance Administration in Bern. From 1960 to 1961 he was financial adviser and chairman of the currency council in Kinshasa, Zaire (then the Belgian Congo) and from 1965 to 1985 a member of the Board of Directors of CIBA and CIBA-GEIGY in Basel. In addition, from 1968 to 1976 he was a member of the advisory board of the Committee of the Mekong River Development Project, an organization operating under UN auspices to promote the economic development of the Mekong basin and grouping Thailand, Laos, Cambodia and Viet Nam.

He undertook a great many missions for the ICRC in some of the world's most intractable trouble-spots: the Middle East during the 1973 Arab-Israeli war, South-East Asia during the conflict in Viet Nam and Cambodia, Bangladesh during the 1971 war between India and Pakistan and Uganda during its period of bloody internal strife. He was assigned by the United Nations to mediate from 1977 to 1984 between Kenya, 
Tanzania and Uganda, the members of the former East African Community, and his success in settling differences between the parties won him the esteem of all concerned.

Victor Umbricht's exceptional abilities as mediator were tremendously useful to the Red Cross Movement in furthering its specific objectives of bringing help and protection to the victims of war. It can thus be said that thousands of men and women throughout the world benefited from his work.

In a tribute to the former Vice-President, Cornelio Sommaruga, President of the ICRC, said: "Victor Umbricht devoted himself to the Red Cross with steadfast optimism, unflagging energy and unfailing dedication.... Victor Umbricht was a true citizen of the world who did not take lightly his position as member of the International Committee. He passionately believed in the ICRC's objectives and strove to ensure that the institution remained faithful to his own principles of total competence, flexibility, discretion and non-paternalistic tolerance.... His hopes and objectives remain our own. We are profoundly indebted to him for the example he set ... and shall do our utmost to follow in his footsteps."

\section{Death of Professor D. Frei member of the ICRC}

Daniel Frei, member of the International Committee of the Red Cross since 1 March 1986, died suddenly on 1 August 1988.

Dr. Frei was born on 24 October 1940 in St. Gallen. When he was 24 years old, he obtained a doctorate in history from the University of Zurich. His studies took him to the London School of Economics and Political Science, the University of Michigan and finally the Graduate Institute of International Studies in Geneva where he received a degree in 1967.

In 1968 he became a lecturer and in 1971 Professor of Political Science at the University of Zurich. He was also Director of the Swiss Institute for International Research.

Dr. Frei was the author of many publications dealing with East-West relations, disarmament, neutrality and international co-operation. He 